Chapman University

Chapman University Digital Commons

Food Science Faculty Articles and Research

Science and Technology Faculty Articles and

Research

9-26-2019

\title{
Development of a DNA Mini-Barcoding Protocol Targeting COI for the Identification of Elasmobranch Species in Shark Cartilage Pills
}

Rowena J. Zahn

Chapman University

Anthony J. Silva

Chapman University

Rosalee S. Hellberg

Chapman University, hellberg@chapman.edu

Follow this and additional works at: https://digitalcommons.chapman.edu/food_science_articles

Part of the Aquaculture and Fisheries Commons, Food Processing Commons, Marine Biology Commons, and the Meat Science Commons

\section{Recommended Citation}

Zahn R.J., Silva A.J. \& Hellberg R.S. (2019). Development of a DNA mini-barcodingprotocol targeting COI for the identification of elasmobranch species in shark cartilage pills, Food Control, 109. 106918. doi: 10.1016/j.foodcont.2019.106918

This Article is brought to you for free and open access by the Science and Technology Faculty Articles and Research at Chapman University Digital Commons. It has been accepted for inclusion in Food Science Faculty Articles and Research by an authorized administrator of Chapman University Digital Commons. For more information, please contact laughtin@chapman.edu. 


\title{
Development of a DNA Mini-Barcoding Protocol Targeting COI for the Identification of Elasmobranch Species in Shark Cartilage Pills
}

\author{
Comments \\ NOTICE: this is the author's version of a work that was accepted for publication in Food Control. Changes \\ resulting from the publishing process, such as peer review, editing, corrections, structural formatting, and \\ other quality control mechanisms may not be reflected in this document. Changes may have been made to this \\ work since it was submitted for publication. A definitive version was subsequently published in Food Control, \\ volume 109, in 2019. DOI: 10.1016/j.foodcont.2019.106918 \\ The Creative Commons license below applies only to this version of the article.
}

\section{Creative Commons License}

\section{(c) 1 (1) 90}

This work is licensed under a Creative Commons Attribution-Noncommercial-No Derivative Works 4.0 License.

\section{Copyright}

Elsevier 
1 Development of a DNA mini-barcoding protocol targeting COI for the identification of

2 elasmobranch species in shark cartilage pills

3

4 Authors: Rowena J. Zahnª Anthony J. Silva ${ }^{\mathrm{a}}$, and Rosalee S. Hellberg ${ }^{\mathrm{a} *}$

5

6 achapman University, Schmid College of Science and Technology, Food Science Program, One

7 University Drive, Orange, CA 92866

8

$9 *$ *orresponding Author

10 Rosalee S. Hellberg, Ph.D.

11 Chapman University

12 Phone: (714) 628-2811

13 E-mail: hellberg@chapman.edu

14

15 Declarations of interest: none

16

17

18

19

20

21

22

23 


\section{Abstract}

25 Many elasmobranch (shark and ray) species are considered threatened and their

26 identification in processed products is important for conservation and authentication purposes.

27 However, identification of elasmobranch species in shark cartilage pills has proven difficult

28 using existing methodologies. The objective of this study was to develop a DNA mini-barcoding

29 protocol using a 130 bp region of the cytochrome $c$ oxidase subunit I (COI) gene for species

30 identification in shark cartilage pills. A total of 22 shark cartilage products underwent DNA

31 extraction in duplicate using the DNeasy Blood and Tissue Kit (Qiagen). The effectiveness of a

32 clean-up step following DNA extraction was analyzed by comparing DNA purity values and

33 polymerase chain reaction (PCR) amplification rates. Next, five different mini-barcode primer

34 sets were compared based on amplification rates, and the three top-performing primer sets were

35 used in DNA sequencing. The incorporation of a clean-up step following DNA extraction

36 showed a slight advantage over DNA extraction alone, with a higher amplification rate (52.3\%

37 vs. 47.8\%) and $A_{260} / A_{230}$ value (3.3 vs. 0.6). The three primer sets selected for DNA mini-

38 barcoding showed DNA sequencing rates of 54.5-65.9\% among the 44 duplicate samples. When

39 the results for all three primer sets were combined, 18 of the 22 shark cartilage products were

40 identified to the species or genus level. On an individual basis, the best-performing primer set

41 identified 16 of the 22 products to the species or genus level. Overall, the protocol developed in

42 this study increased the identification rate for elasmobranches in cartilage products by more than

43 2-fold as compared to previous research.

44 Keywords: DNA barcoding; DNA extraction; elasmobranch; shark cartilage; species

45 identification

46 


\section{1. Introduction}

The skeletons of sharks and other elasmobranch species are composed of cartilage,

49 which is a connective tissue rich in proteins such as collagens and proteoglycans (Sim, et al.,

50 2007). Shark cartilage has been investigated as a possible treatment for numerous medical

51 conditions, including arthritis and cancer (Merly \& Smith, 2015; Mondo, et al., 2014; Sim, et

52 al., 2007). Due to its purported health benefits, shark cartilage is widely used as a dietary

53 supplement. It is produced by separating the cartilage from the meat and drying it into a

54 powder for use in capsules or tablets (Rose, 1996). Despite the numerous shark cartilage

55 supplements available on the market, global trade information on these products, including

56 the species used, is extremely limited (Clarke, 2004; Dent \& Clarke, 2015).

57 Sharks and other elasmobranchs are especially vulnerable to overfishing due to

58 biological factors such as low fecundity and long reproductive cycles (Bräutigam, et al.,

59 2015; Ferretti, Worm, Britten, Heithaus, \& Lotze, 2010). Among the 1,038 shark and ray

60 species assessed by the International Union for the Conservation of Nature (IUCN), close to

$6120 \%$ are considered Critically Endangered, Endangered, or Vulnerable, and an additional

62 12\% are categorized as Near Threatened (Bräutigam, et al., 2015). The Convention on

63 International Trade in Endangered Species of Wild Fauna and Flora (CITES) also lists 13

64 elasmobranch species or species groups in Appendix II, meaning that export permits are

65 required for international trade of these animals (CITES, 2019). Shark cartilage pills have

66 been reported to contain Near Threatened, Vulnerable, and Endangered elasmobranch

67 species, including silky shark (Carcharhinus falciformis), a CITES-listed species (Hellberg et

68 al. 2019). With growing concern over exploitation of global elasmobranch populations and a 
69 lack of trade data, improved methods to identify and track species in shark cartilage

70 supplements are needed.

71 DNA-based techniques, such as DNA barcoding and species-specific polymerase

72 chain reaction (PCR), are commonly used to identify elasmobranch species when

73 morphological indicators are lacking (Appleyard, White, Vieira, \& Sabub, 2018; Dudgeon, et

74 al., 2012; Hanner, Naaum, \& Shivji, 2016; Rodrigues-Filho, Pinhal, Sondre, \& Vallinoto,

75 2012). While species-specific PCR is preferable for targeted approaches, DNA barcoding is

76 more appropriate for applications involving a wide range of species, such as shark cartilage

77 supplements. DNA barcoding is a sequencing-based method for species identification that

78 uses universal primer sets to target a short, standardized region of the genome (Hebert,

79 Cywinska, Ball, \& DeWaard, 2003). The most common genetic region targeted for the

80 identification of animal species is a $\sim 650$ base pair (bp) region of the mitochondrial gene

81 coding for cytochrome $c$ oxidase subunit I (CO1). However, it has proven challenging to

82 recover the full-length DNA barcode from highly processed samples due to DNA

83 fragmentation (Fields, Abercrombie, Eng, Feldheim, \& Chapman, 2015; Shokralla, Hellberg,

84 Handy, King, \& Hajibabaei, 2015).

85 An alternative approach for identification of processed samples is DNA mini-barcoding,

86 which targets shorter regions of the full-length barcode. For example, Shokralla et al. (2015)

87 developed a fish mini-barcoding system using the cytochrome $c$ oxidase subunit I (COI) gene

88 that enabled identification of $88.6 \%$ of processed fish products tested, as compared to $20.5 \%$

89 identification success with full barcoding. DNA barcoding and mini-barcoding techniques

90 have been used to identify elasmobranch species in a range of commercial products,

91 including dried shark fin, shark meat, and shark fin soup (Barbuto, et al., 2010; Cardeñosa, et 
92 al., 2017; Chuang, Hung, Chang, Huang, \& Shiao, 2016; Fields, et al., 2015; R.S. Hellberg,

93 Isaacs, \& Hernandez, 2019; O'Bryhim, Parsons, \& Lance, 2017; Steinke, et al., 2017). A

94 number of studies have also differentiated shark species utilizing DNA barcoding combined

95 with character-based analysis, which is based on the presence or absence of specific

96 nucleotides determined to be diagnostic for a given species (Fields et al. 2015; Velez-Zuazo

97 et al. 2015; Wong et al. 2009).

98 DNA barcoding of shark cartilage supplements has proven challenging, likely due to

99 factors such as DNA degradation during processing, the presence of PCR inhibitors, and the

100 possibility of multiple species in one product (R.S. Hellberg, et al., 2019). Hellberg et al. (2019)

101 utilized a combination of COI full and mini-barcoding to identify elasmobranch species in shark

102 products, including cartilage supplements. Full-length barcoding of shark cartilage supplements

103 enabled identification in only $20.7 \%$ of these products, as compared to $51.7 \%$ of supplements

104 identified with shark mini-barcoding. Optimization of DNA extraction and amplification

105 techniques may improve DNA barcoding performance, thereby enabling identification of species

106 in a greater number of shark cartilage pills.

107 The objective of this study was to develop a mini-barcoding protocol for the

108 identification of elasmobranch species in shark cartilage pills through optimization of DNA

109 extraction, amplification, and sequencing techniques. The effectiveness of a clean-up step

110 following DNA extraction was examined; five mini-barcoding primer sets were compared based

111 on PCR amplification rates; and uni-directional sequencing was compared to bi-directional

112 sequencing for the three top-performing primer sets. 


\section{Methods}

\section{2.1 Sample collection and preparation}

A subset $(n=22)$ of the shark cartilage pills tested by Hellberg et al. (2019) were selected

118 for use in this study. All products that failed PCR or sequencing in the previous study were

119 selected $(n=9)$, along with samples that represented the range of species detected in shark

120 cartilage pills $(\mathrm{n}=13)$. Among the 13 samples previously identified, Hellberg et al. (2019)

121 detected a single species in 11 products and a combination of two species in 2 products. A

122 composite sample was made for each product by combining three pills. Pills in capsule form

123 were twisted open to release the cartilage powder and tablets were ground together using a sterile

124 mortar and pestle. The composite samples were stored at room temperature in sterile 50-mL

125 Falcon tubes (Corning, Corning, NY).

$126 \quad 2.2$ Comparison of DNA extraction methods

127 DNA extraction was performed on 25 mg of each composite sample using the DNeasy

128 Blood and Tissue Kit (Qiagen, Valencia, CA), Spin-Column protocol. Sample lysis was carried

129 out for $2 \mathrm{~h}$ at $56^{\circ} \mathrm{C}$ with pulse vortexing every $30 \mathrm{~min}$. DNA was eluted with $60 \mu \mathrm{L}$ of AE buffer

130 pre-heated to $37^{\circ} \mathrm{C}$. All samples were extracted in duplicate and a reagent blank negative control

131 was included alongside each set of DNA extractions. The concentration and purity of each DNA

132 extract was measured using a Biophotometer Plus (Eppendorf, Happauge, NY). All samples

133 underwent PCR as described below with the original shark mini-barcode primer set (Table 1)

134 used in Fields et al. (2015). Amplification results were determined by gel electrophoresis, as

135 described below. The remaining portion of each duplicate DNA extract $(\sim 50 \mu \mathrm{L})$ underwent a

136 clean-up step with the PowerClean Pro CleanUp Kit (Qiagen), according to the manufacturer’s

137 instructions, with the exception that AE buffer was used in the final elution step. The 
concentration and purity of the DNeasy Kit plus PowerClean Kit DNA extracts were measured

139 with a Biophotometer Plus. All samples underwent PCR using the original shark mini-barcode

140 primers, followed by gel electrophoresis (as described below). The DNA concentration, DNA

141 purity, PCR amplification rates, and PCR amplification consistency for samples extracted with

142 the DNeasy Kit were compared to those of the samples extracted with the DNeasy Kit plus

143 PowerClean Kit to determine the optimal method to be used for the PCR primer comparison

144 studies.

1452.3 PCR primer comparison

146 In order to compare PCR primer sets, DNA was extracted in duplicate from each sample

147 using the DNeasy Blood and Tissue Kit plus the PowerClean Pro CleanUp Kit. Each DNA

148 extract was then tested against five different primer sets (Table 1): the original shark mini-

149 barcode primer set (Fields, et al., 2015), two variations of the shark mini-barcode primer set (V1

150 and V2, designed in the current study), and two primer sets (SH-D and SH-E) used in a previous

151 study on fish species identification (Shokralla, et al., 2015). The V1 and V2 primer sets were

152 designed based on comparison with an alignment of 1049 elasmobranch sequences obtained

153 from GenBank (Accession numbers: FJ518910-FJ519800, FJ519802-FJ519959; Wong, et al.,

154 2009). M13 tails were attached to the SH-D, SH-E, and forward shark mini-barcode primers to

155 facilitate DNA sequencing (Table 1). PCR for the shark mini-barcode primer set and its

156 variations (V1 and V2) was carried out using $12.5 \mu \mathrm{L}$ HotStar Taq Master Mix (Qiagen), 10.5

$157 \mu \mathrm{L}$ of molecular-grade sterile water, $0.5 \mu \mathrm{L}$ of $10 \mu \mathrm{M}$ forward primer cocktail, $0.5 \mu \mathrm{L}$ of $10 \mu \mathrm{M}$

158 reverse primer, and $1.0 \mu \mathrm{L}$ of template DNA. PCR for the SH-D and SH-E primer sets was

159 carried out using the same preparation mix as the shark mini-barcode primers, except that $9.5 \mu \mathrm{L}$

160 of sterile water, and $2.0 \mu \mathrm{L}$ of template DNA were used. A no-template control (NTC) 
161 containing sterile water in place of DNA was included in each set of reactions. Primers were

162 synthesized by Integrated DNA Technologies (Coralville, IA) and a Mastercycler Nexus

163 Gradient Thermal Cycler (Eppendorf) was used to carry out PCR.

164 The cycling conditions for shark mini-barcoding were: $95^{\circ} \mathrm{C}$ for $15 \mathrm{~min}$; 35 cycles of

$16594^{\circ} \mathrm{C}$ for $1 \mathrm{~min}, 52^{\circ} \mathrm{C}$ for $1 \mathrm{~min}$, and $72^{\circ} \mathrm{C}$ for $2 \mathrm{~min}$; and a final extension step at $72^{\circ} \mathrm{C}$ for 5 min

166 (R.S. Hellberg, et al., 2019). The same cycling conditions were used for the V1 and V2 shark

167 mini-barcoding primer sets except that the annealing temperatures were $46^{\circ} \mathrm{C}$ and $54^{\circ} \mathrm{C}$,

168 respectively. These optimal annealing temperatures were determined based on the results of

169 gradient PCR at a temperature range of $43-60^{\circ} \mathrm{C}$ followed by gel electrophoresis, as described

170 below (Shokralla, et al., 2015). The cycling conditions for the SH-D primer set were: $95^{\circ} \mathrm{C}$ for

$171 \quad 15 \mathrm{~min} ; 35$ cycles of $94^{\circ} \mathrm{C}$ for $40 \mathrm{~s}, 50^{\circ} \mathrm{C}$ for $1 \mathrm{~min}$, and $72^{\circ} \mathrm{C}$ for $30 \mathrm{~s}$; and a final extension step

172 at $72^{\circ} \mathrm{C}$ for $5 \mathrm{~min}$. The cycling conditions for the SH-E primer set were: $95^{\circ} \mathrm{C}$ for $15 \mathrm{~min} ; 35$

173 cycles of $94^{\circ} \mathrm{C}$ for $40 \mathrm{~s}, 46^{\circ} \mathrm{C}$ for $1 \mathrm{~min}$, and $72^{\circ} \mathrm{C}$ for $30 \mathrm{~s}$; and a final extension step at $72^{\circ} \mathrm{C}$ for

1745 min.

1752.4 Gel electrophoresis

176 PCR products $(4 \mu \mathrm{L})$ were loaded onto $2 \%$ agarose E-Gels (Life Technologies, Carlsbad,

177 CA) and run using the E-Gel 0.8-2.0\% Program on an E-Gel iBase (Life Technologies) for 15

178 min (Rosalee S. Hellberg, Kawalek, Van, Shen, \& Williams-Hill, 2014). The results were

179 visualized with FOTO/Analyst Express (Fotodyne, Hartland, WI) and Transilluminator FBDLT-

18088 (Fisher Scientific, Waltham, MA) combined with FOTO/Analyst PCImage (version 5.0.0.0,

181 Fotodyne). Samples with visible bands of the expected size following electrophoresis were

182 considered positive for PCR amplification. 
Primer sets with amplification rates equal to or greater than the original shark mini-

186 barcode primer set (shark mini-barcode V1 and V2) were further examined based on DNA

187 sequencing results. Samples that produced PCR amplicons visible with gel electrophoresis

188 underwent PCR clean-up using a 4-fold dilution of ExoSAP-IT, as described in Weigt et al.

189 (2012). The products were then submitted to GenScript (Piscataway, NJ) for DNA sequencing.

190 For bi-directional sequencing, samples were sequenced in both directions using the M13 forward

191 primer and the reverse primer. For uni-directional sequencing, only the sequence read from the

192 M13 forward primer was analyzed (Fields, et al., 2015). The resulting sequencing files were

193 assembled, edited, and trimmed to the mini-barcode region (127 bp) using Geneious R7

194 (Biomatters, Ltd., Auckland, New Zealand) (Kearse, et al., 2012). Sequences were only

195 considered acceptable if they had $<2 \%$ ambiguities and were $\geq 64 \mathrm{bp}$ in length (at least $50 \%$

196 coverage of the mini-barcode region). The resulting sequences were initially searched against

197 the Barcode of Life Database (BOLD) Animal Identification Request Engine

198 (http://www.boldsystems.org/), Species Level Barcodes (November 2018). Sequences that could

199 not be identified in BOLD were next searched against GenBank using the Nucleotide Basic

200 Local Alignment Search Tool (BLAST; http://blast.ncbi.nlm.nih.gov/Blast.cgi). Top species

201 matches obtained through these databases were further examined by determining the source of

202 the entry and checking to see whether the entry was previously identified as a misidentified

203 specimen. Additionally, character-based analysis was applied where applicable to assist with

204 species identification (Fields, et al., 2015; Velez-Zuazo, Alfaro-Shigueto, Mangel, Papa, \&

205 Agnarsson, 2015; Wong, Shivji, \& Hanner, 2009). Sequences with equivalent top matches to 
206 species from multiple genera at less than 98\% similarity were not considered successful

207 identifications.

208 2.6 Statistical analysis

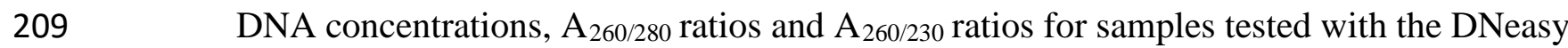

210 Kit alone and the DNeasy Kit plus PowerClean Kit were compared using the Wilcoxon signed-

211 rank test, with a pre-determined level of significance of $p<0.05$. PCR amplification rates and

212 amplification consistency were compared for samples tested with the DNeasy Kit alone and the

213 DNeasy Kit plus PowerClean Kit using McNemar's test, with a level of significance of $p<0.05$.

214 Results for PCR amplification, DNA sequencing, and species identification for the various

215 primer sets were compared using Cochran’s Q test, with a level of significance of $p<0.05$.

216 Statistically significant results were compared with Dunn’s post-hoc test with the Bonferroni

217 correction (adjusted $p<0.05)$. The sequence lengths, quality scores (\% HQ), and percent

218 ambiguities were compared across the various primer sets and sequencing methods tested using

219 the Kruskal-Wallis H test and Dunn's post hoc test with the Bonferroni correction (adjusted p <

220 0.05). All analyses were carried out with IBM SPSS Statistics 23 (Armonk, New York, USA).

\section{3. Results and Discussion}

2223.1 Comparison of DNA extraction methods

223 As shown in Table 2, the average DNA concentration of the samples extracted with the

224 DNeasy Kit $(69.6 \pm 70.3 \mathrm{ng} / \mathrm{ul})$ was significantly higher than that for samples extracted with the

225 DNeasy Kit plus PowerClean Kit (23.4 \pm 13.1 ng/ul), according to a Wilcoxon signed-rank test

$226(p<0.05)$. The average $\mathrm{A}_{260} / \mathrm{A}_{280}$ ratios for samples extracted with the DNeasy Kit $(1.7 \pm 0.5)$

227 and the DNeasy Kit plus PowerClean Kit $(1.6 \pm 0.4)$ were not significantly different and were

228 close to the optimal ratio of $~ 1.8$ for pure DNA (Desjardins \& Conklin, 2010). The $\mathrm{A}_{260} / \mathrm{A}_{280}$ 
229 ratios could not be determined for 7 of the 44 replicates tested with the DNeasy Kit alone

230 because the $\mathrm{A}_{280}$ value was not within the measuring range. Paired samples with missing data

231 were excluded from the statistical analysis, resulting in a total of 37 paired data points analyzed

232 by the Wilcoxon signed-rank test. The average $A_{260} / A_{230}$ ratio for samples extracted with the

233 DNeasy Kit $(0.6 \pm 0.3)$ was significantly lower than that for 8 of 22 samples extracted with the

234 DNeasy Kit plus PowerClean Kit $(3.3 \pm 3.0)$. The $A_{260} / A_{230}$ ratio could not be determined for a 235 portion of the 44 replicates tested with the DNeasy Kit alone $(n=3)$ and the DNeasy Kit plus

236 PowerClean Kit $(n=14)$ because the $A_{230}$ value was not within the measuring range. Paired

237 samples with missing data were excluded from the statistical analysis, resulting in a total of 27

238 paired data points analyzed by the Wilcoxon signed-rank test. The lower $\mathrm{A}_{260} / \mathrm{A}_{230}$ ratios for

239 samples extracted with the DNeasy Kit indicate the presence of contaminants that were removed

240 by the PowerClean Kit. These may have included residual guanidine from the silica column in

241 the DNeasy Kit or carbohydrates in the shark cartilage pills, such as cellulose, that were carried

242 over during extraction (Matlock, 2015).

243 PCR amplification rates for the two extraction methods were compared using the original

244 shark mini-barcode primer set (for example, see Supplementary Figure S1). As shown in Table

245 2, use of the DNeasy Kit plus PowerClean Kit resulted in visible bands in the gel for 23 of the 44

246 duplicate samples for a success rate of $52.3 \%$, as compared to a success rate of $47.8 \%$ with the

247 DNeasy Kit alone. Samples extracted with the DNeasy Kit plus PowerClean Kit also showed

248 greater agreement among duplicate samples (95.5\%) as compared to the DNeasy Kit (77.3\%).

249 However, there were no significant differences between the two methods on the basis of PCR

250 amplification rate or consistency (McNemar's test, $p>0.05$ ). 
252 for extraction of DNA from shark cartilage pills. This was based on the significant increase in

253 the $\mathrm{A}_{260} / \mathrm{A}_{230}$ values obtained with this method combined with the higher PCR amplification rate

254 and amplification consistency as compared to the DNeasy Kit alone. Although the DNeasy Kit

255 plus PowerClean Kit led to a significantly reduced DNA concentration, the DNA yield was

256 sufficient to allow for PCR amplification. These results indicate that the additional clean-up

257 steps carried out with the PowerClean Kit allowed for the removal of PCR inhibitors such as

258 carbohydrates and guanidine, thus improving PCR amplification rates and consistency.

\subsection{PCR primer comparison}

260 Out of the 44 duplicate samples tested with the five mini-barcode primer sets, 34 (77.3\%)

261 could be amplified with at least one primer set (Fig. 1). On an individual basis, the shark mini-

262 barcode V1 and V2 primer sets were the most successful (68.2\%), followed by the original shark

263 mini-barcode primer set (56.8\%). The amplification rate for the mini SH-D and mini SH-E

264 primer sets (22.7\%) was significantly lower than the rates obtained with the original shark mini-

265 barcode, shark mini-barcode V1, and shark mini-barcode V2, according to a Cochran’s Q test

266 followed by Dunn's test with the Bonferroni correction $(p<0.05)$. The decreased amplification

267 rates observed for the mini SH-D and SH-E primer sets were likely because they were not

268 designed for the specific amplification of shark species, but rather for the universal amplification

269 of processed fish species. On the other hand, the shark mini-barcode primer sets utilize a

270 universal forward fish cocktail combined with a reverse primer specifically designed to amplify

271 shark species (Table 1). Based on the results of PCR amplification, the original shark mini-

272 barcode and the shark mini-barcode V1 and V2 primer sets were selected for use in DNA

273 sequencing. 


\subsection{DNA sequencing}

275 Out of the 44 duplicate samples sequenced with the three shark mini-barcode primer sets,

27633 (75\%) were sequenced with at least one primer set (Table 3). Sequencing rates for the

277 individual primer sets and sequencing methods (uni-directional and bi-directional) were not

278 significantly different according to Cochran’s Q test $(p>0.05)$. The shark mini-barcode V2

279 primer set showed the highest sequencing rates of $65.9 \%$ and $63.6 \%$ for bi-directional and uni-

280 directional methods, respectively. Sequencing rates for the other primer sets were all $<60 \%$.

281 When comparing bi-directional sequencing with uni-directional sequencing, the former had a

282 higher sequencing rate for two out of the three primer sets (V1 and V2).

283

The average sequence length (113 $\pm 16 \mathrm{bp})$ for all primer sets combined was close to the

284 target sequence length of $127 \mathrm{bp}$ and the average percent ambiguities was low, at $0.09 \pm 0.33 \%$

285 (Table 3). The sequence lengths obtained with bi-directional sequencing for each primer set

286 were significantly higher than those obtained with uni-directional sequencing, according to the

287 Kruskal-Wallis H test and Dunn's post hoc test with the Bonferroni correction, adjusted $p<$

288 0.05). The bi-directional sequences showed a combined average of $0.18 \pm 0.44 \%$ ambiguities,

289 with no significant differences across the three primer sets.

290 As shown in Table 3, the sequencing quality scores had a combined average of $44.2 \pm$

$29130.6 \%$ HQ. Similar to the results for sequencing length, the average quality score was highest

292 for the bi-directional results ( $54.3 \pm 32.9 \% \mathrm{HQ}$ ) as compared to the uni-directional results (33.8

$293 \pm 24.1 \%$ HQ). However, the only statistical difference was that the quality score for the bi-

294 directional shark mini-barcode $(70.6 \pm 17.1 \%$ HQ) was significantly higher than the other quality

295 scores, according to the Kruskal-Wallis H test and Dunn's post hoc test with the Bonferroni

296 correction (adjusted $p<0.05$ ). The reduced quality of the sequences obtained with the shark 
297 mini-barcode V1 and V2 primer sets is likely due to the use of degeneracies in the reverse

298 primers (Table 1), which may have resulted in co-amplification of other gene regions and/or

299 multiple mini-barcodes in products with mixed species.

300 Overall, bi-directional sequencing showed greater performance as compared to uni-

301 directional sequencing, with improvements in sequencing rates, sequence lengths, and quality

302 scores. When comparing the individual primer sets, the shark mini-barcode V2 primer set

303 allowed for the greatest sequencing rate, while the original shark mini-barcode primer set

304 allowed for the greatest sequence quality and length.

3053.4 Species identification

306 The three shark mini-barcode primer sets were next evaluated for their ability to identify

307 elasmobranch species in the shark cartilage pills (Table 4). This analysis was focused on the

308 results of bi-directional sequencing because of the improved performance discussed above for

309 this method. Overall, 18 of the 22 shark cartilage products (81.8\%) could be identified to the

310 species or genus level with at least one of the primer sets. On an individual basis, the shark

311 mini-barcode V2 primer set identified the greatest percentage of products (72.7\%) to the species

312 or genus level, followed by the original shark mini-barcode primer set (63.6\%), and the shark

313 mini-barcode V1 primer set (59.1\%). These percentages are an improvement over the previous

314 identification rate (36.4\%) reported by Hellberg et al. (2019) for the same set of 22 shark

315 cartilage products amplified uni-directionally with the original shark mini-barcode primer set.

316 The increased identification rates observed in the current study were likely due to a combination

317 of improvements made to the methodology, including the use of a composite sample for DNA

318 extraction, testing of duplicate samples, incorporation of the PowerClean Kit into the extraction

319 process, and the use of modified shark mini-barcode primer sets. The benefit of testing samples 
320 in duplicate is illustrated by the fact that there were 3-5 samples per primer set for which only

321 one of the duplicate samples could be identified (Table 4).

322 The modified primer sets (V1 and V2) used in the current study enabled the identification

323 of two species that were not detected with the original shark mini-barcode primer set: winter

324 skate (Leucoraja ocellata) and spiny dogfish (Squalus acanthias). These species are considered

325 endangered and vulnerable, respectively, according to the IUCN Red List of Threatened Species

326 (http://www.iucnredlist.org/). Although the samples identified as L. ocellata also matched a

327 sequence labeled as little skate (Leucoraja erinacea), this sequence was previously reported to be

328 misidentified and actually belong to winter skate (Coulson, et al., 2011; R.S. Hellberg, et al.,

329 2019). The inability of the original shark mini-barcode primer set to detect $L$. ocellata or $S$.

330 acanthias in the shark cartilage products is consistent with the results of Hellberg et al. (2019).

331 In contrast, Fields et al. (2015) reported the ability to identify S. acanthias in shark fin soup

332 using this primer set. For optimal identification of species in shark cartilage pills, it is

333 recommended that samples be tested against all three primer sets described here (i.e., original

334 shark mini-barcode, V1, and V2).

3353.5 Shark mini-barcoding considerations

336 An important consideration with regard to DNA barcoding is the level of genetic

337 similarity achieved between the query sequence and the reference sequences. Traditionally, a

338 cut-off of $>2 \%$ genetic divergence has been applied to differentiate fish species based on the full

339 barcode (Handy, et al., 2011). However, many of the mini-barcode sequences obtained in the

340 current study showed multiple species matches with $\geq 98 \%$ genetic similarity. This occurred

341 most frequently with the Carcharhinus species, which are closely related and have been

342 previously reported to show high genetic similarity across the DNA barcode region (R.S. 
343 Hellberg, et al., 2019; Ward, Holmes, White, \& Last, 2008). While the full-length DNA barcode

344 can effectively differentiate many of these species (e.g., see Appleyard et al. 2018; Wong et al.

345 2009), the shorter amplicon generated with mini-barcoding showed reduced differentiation

346 capability when relying on a distance-based approach. In some of these cases, the use of

347 character-based identification keys developed in previous studies (Fields, et al., 2015; Velez-

348 Zuazo, et al., 2015; Wong, et al., 2009) enabled differentiation (Table 4). For example, many

349 samples showed equivalent genetic matches to multiple members of the Carcharhinus genus in

350 BOLD and/or GenBank. When a set of diagnostic nucleotides published in Wong et al. (2009)

351 was applied to these sequences, it allowed for the identification of silky shark, a CITES-listed

352 species, in five of these samples.

353 In several instances, a secondary match showed $>99.22 \%$ genetic similarity to the top

354 match in BOLD, corresponding to less than 1 nucleotide difference in a 127 bp sequence. These

355 results were often due to the presence of an ambiguity or gap in the sequence of the secondary

356 match and there is potential for a mis-identification to occur when additional consideration is not

357 given to the secondary match. For example, one of the PS07 shark mini-barcode V2 sequences

358 showed a top match (97.58\%) to scalloped hammerhead shark (Sphyrna lewini) and a secondary

359 match (97.32\%) to spot-tail shark (Carcharhinus sorrah) in BOLD. However, character analysis

360 revealed that the query sequence was not S. lewini due to the absence of diagnostic nucleotides

361 described in Fields et al. (2015) and the sample was instead identified as C. sorrah.

362 The results discussed above support the use of character-based analysis in combination

363 with genetic similarity values, as recommended in previous studies on shark DNA barcoding

364 (Fields, et al., 2015; Velez-Zuazo, et al., 2015; Wong, et al., 2009). However, it should be noted

365 that character-based keys are limited in species number, subject to change, and sometimes cannot 
366 be used with the mini-barcode region targeted in this study. Therefore, confirmation of species

367 for enforcement purposes should include an attempt to sequence the full-length barcode and/or a

368 longer mini-barcode, such as that described in Cardeñosa et al. (2017). In cases where there is <

3691 nucleotide difference between the primary and secondary species matches and character

370 analysis cannot be utilized, it may be more appropriate to report all species rather than relying

371 only on the top match.

372 Finally, it is important to note that shark cartilage pills are a highly processed product

373 with the possibility for species mixtures. While species were identified in the majority of

374 samples in the current study, standard DNA barcoding and mini-barcoding do not enable

375 simultaneous identification of multiple species in a single sample. Therefore, additional research

376 should be conducted to explore the use of mini-barcodes combined with next-generation

377 sequencing or PCR cloning to identify species in mixed samples.

\section{4. Conclusions}

379 This study describes the development of an effective method for the DNA-based

380 identification of elasmobranch species in shark cartilage pills. Overall, the combined results for

381 the three shark mini-barcode primer sets tested in this study allowed for species or genus-level

382 identification in $81.8 \%$ of shark cartilage products. This was a marked improvement over

383 previous research that was only able to identify $36.4 \%$ of these products to the species or genus-

384 level. The methodology described in the current study is expected to facilitate conservation

385 efforts and monitoring of international trade by providing an improved protocol to determine

386 whether shark cartilage pills are mislabeled and/or contain at-risk species. These improvements

387 may also serve to increase mini-barcoding identification rates for other highly processed

388 commercial shark products, such as shark fin soup. Future research should explore the utility of 
shark mini-barcodes combined with next-generation sequencing and/or PCR cloning approaches

390 to identify mixed species in shark products. Additionally, the ability of a longer mini-barcode to

391 amplify in these products should be examined in order to improve differentiation of closely

392 related species.

\section{5. Acknowledgements}

394 This work was supported by Chapman University Schmid College of Science and

395 Technology. The funding entity was not involved with the study design; the collection, analysis 396 and interpretation of data; report writing; or the decision to submit the article for publication.

\section{6. References}

398 Appleyard, S. A., White, W. T., Vieira, S., \& Sabub, B. (2018). Artisanal shark fishing in Milne 399 Bay Province, Papua New Guinea: biomass estimation from genetically identified shark $400 \quad$ and ray fins. Sci. Rep., 8(1), 6693.

401 Barbuto, M., Galimberti, A., Ferri, E., Labra, M., Malandra, R., Galli, P., \& Casiraghi, M.

402 (2010). DNA barcoding reveals fraudulent substitutions in shark seafood products: The Italian case of "palombo" (Mustelus spp.). Food Res Int, 43(1), 376-381.

404 Bräutigam, A., Callow, M., Campbell, I. R., Camhi, M. D., Cornish, A. S., Dulvy, N. K., 405 Fordham, S. V., Fowler, S. L., Hood, A. R., McClennen, C., Reuter, E. L., Sant, G., 406 Simpfendorfer, C. A., \& Welch, D. J. (2015). Global Priorities for Conserving Sharks and 407 Rays: A 2015-2025 Strategy. Global Sharks and Rays Initiative.

408 Cardeñosa, D., Fields, A., Abercrombie, D., Feldheim, K., Shea, S. K. H., \& Chapman, D. D. 409 (2017). A multiplex PCR mini-barcode assay to identify processed shark products in the $410 \quad$ global trade. PLoS ONE, 12(10), e0185368. 
411 Chuang, P. S., Hung, T. C., Chang, H. A., Huang, C. K., \& Shiao, J. C. (2016). The species and

412

413

414

415

416

417

418

419

420

421

422

423

424

425

426

427

428

429

430

431

432

433

origin of shark fins in Taiwan's fishing ports, markets, and customs detention: A DNA barcoding analysis. PLoS ONE, 11(1), e0147290.

CITES. (2019). Convention on International Trade in Endangered Species of Wild Fauna and Flora. https://www.cites.org/eng (Accessed 4/12/2019).

Clarke, S. (2004). Shark Product Trade in Hong Kong and Mainland China and Implementation of the CITES Shark Listings.

Coulson, M. W., Denti, D., Van Guelpen, L., Miri, C., Kenchington, E., \& Bentzen, P. (2011). DNA barcoding of Canada's skates. Mol Ecol Resour, 11(6), 968-978.

Dent, F., \& Clarke, S. (2015). State of the Global Market for Shark Products. FAO Fisheries and Aquaculture Technical Paper No. 590. Rome, FAO. 187 pp.

Desjardins, P., \& Conklin, D. (2010). NanoDrop microvolume quantitation of nucleic acids. $J$ Vis Exp, 45, e2565.

Dudgeon, C. L., Blower, D. C., Broderick, D., Giles, J. L., Holmes, B. J., Kashiwagi, T., Krueck, N. C., Morgan, J. A. T., Tillett, B. J., \& Ovenden, J. R. (2012). A review of the application of molecular genetics for fisheries management and conservation of sharks and rays. J Fish Biol, 80(5), 1789-1843.

Ferretti, F., Worm, B., Britten, G. L., Heithaus, M. R., \& Lotze, H. K. (2010). Patterns and ecosystem consequences of shark declines in the ocean. Ecology Letters, 13(8), 10551071.

Fields, A. T., Abercrombie, D. L., Eng, R., Feldheim, K., \& Chapman, D. D. (2015). A novel mini-DNA barcoding assay to identify processed fins from internationally protected shark species. PLoS One, 10(2), e0114844. 
434 Handy, S. M., Deeds, J. R., Ivanova, N. V., Hebert, P. D. N., Hanner, R., Ormos, A., Weigt, L.

435

436

437

438

439

440

441

442

443

444

445

446

447

448

449

450

451

452

453

454

455

456

A., Moore, M. M., Hellberg, R. S., \& Yancy, H. F. (2011). Single laboratory validated method for DNA-barcoding for the species identification of fish for FDA regulatory compliance (Vol. 2017). Silver Spring, MD: United States Food and Drug Administration.

Hanner, R. H., Naaum, A. M., \& Shivji, M. S. (2016). DNA-Based Authentication of Shark Products and Implications for Conservation and Management. In R. H. Hanner \& A. M. Nauum (Eds.), Seafood Authenticity and Traceability: A DNA-based Perspective (pp. 171-179). San Diego, CA, USA: Academic Press/Elsevier.

Hebert, P. D. N., Cywinska, A., Ball, S. L., \& DeWaard, J. R. (2003). Biological identifications through DNA barcodes. Proc. R. Soc. B Biol. Sci., 270(1512), 313-321.

Hellberg, R. S., Isaacs, R. B., \& Hernandez, E. L. (2019). Identification of shark species in commercial products using DNA barcoding. Fish Res, 210(February), 81-88.

Hellberg, R. S., Kawalek, M. D., Van, K. T., Shen, Y., \& Williams-Hill, D. M. (2014). Comparison of DNA extraction and PCR setup methods for use in high-throughput DNA barcoding of fish species. Food Anal Methods, 7(10), 1950-1959.

Kearse, M., Moir, R., Wilson, A., Stones-Havas, S., Cheung, M., Sturrock, S., Buxton, S., Cooper, A., Markowitz, S., Duran, C., Thierer, T., Ashton, B., Meinties, P., \& Drummond, A. (2012). Geneious Basic: an integrated and extendable desktop software platform for the organization and analysis of sequence data. Bioinformatics, 28(12), 1647-1649.

Matlock, B. (2015). Assessment of Nucleic Acid Purity. NanoDrop Spectrophotometers, Technical Note 52646. 
457 Merly, L., \& Smith, S. L. (2015). Pro-inflammatory properties of shark cartilage supplement.

458 Immunopharmacol Immunotoxicol, 37(2), 140-147.

459 Mondo, K., Glover, W. B., Murch, S. J., Liu, G. L., Cai, Y., Davis, D. A., \& Mash, D. C. (2014).

460 Environmental neurotoxins beta-N-methylamino-L-alanine (BMAA) and mercury in

461 shark cartilage dietary supplements. Food Chem Toxicol, 70, 26-32.

462 O'Bryhim, J. R., Parsons, E. C. M., \& Lance, S. L. (2017). Forensic species identification of 463 elasmobranch products sold in Costa Rican markets. Fish Res, 186, 144-150.

464 Rodrigues-Filho, L. F., Pinhal, D., Sondre, D., \& Vallinoto, M. (2012). Shark DNA

465 Forensics: Applications and Impacts on Genetic Diversity. In M. Caliskan (Ed.),

466 Analysis of Genetic Variation in Animals (pp. 269-286). Rijeka, Croatia: InTech.

467 Rose, D. (1996). An Overview of World Trade in Sharks and Other Cartilaginous Fishes. A

468 TRAFFIC Network Report. 106 p.

469 Shokralla, S., Hellberg, R. S., Handy, S. M., King, I., \& Hajibabaei, M. (2015). A DNA mini-

$470 \quad$ barcoding system for authentication of processed fish products. Sci Rep, 5, 15894.

471 Sim, J.-S., Im, A. R., Cho, S. M., Jang, H. J., Jo, J. H., \& Kim, Y. S. (2007). Evaluation of

472 chondroitin sulfate in shark cartilage powder as a dietary supplement: Raw materials and

$473 \quad$ finished products. Food Chem, 101(2), 532-539.

474 Steinke, D., Bernard, A. M., Horn, R. L., Hilton, P., Hanner, R., \& Shivji, M. S. (2017). DNA

475 analysis of traded shark fins and mobulid gill plates reveals a high proportion of species

476 of conservation concern. Sci Rep, 7, 9505.

477 Velez-Zuazo, X., Alfaro-Shigueto, J., Mangel, J., Papa, R., \& Agnarsson, I. (2015). What

478 barcode sequencing reveals about the shark fishery in Peru. Fish Res, 161, 34-41. 
479 Ward, R. D., Holmes, B. H., White, W. T., \& Last, P. R. (2008). DNA barcoding Australasian 480 chondrichthyans: results and potential uses in conservation. Mar Freshwater Res, 59(1), $481 \quad 57-71$

482 Weigt, L., Driskell, A., Baldwin, C., \& Ormos, A. (2012). DNA barcoding fishes. In W. J. Kress 483 \& D. L. Ericksono (Eds.), DNA barcodes methods and protocols (pp. 109-126). New $484 \quad$ York: Humana Press.

485 Wong, E. H. K., Shivji, M. S., \& Hanner, R. H. (2009). Identifying sharks with DNA barcodes: 486 assessing the utility of a nucleotide diagnostic approach. Mol Ecol Resour, 9, 243-256. 


\section{Figure Captions}

Figure 1. PCR amplification rates obtained for duplicate shark cartilage samples $(n=44)$ tested with the five primer sets compared in this study. The 'Combined' column shows the results for all primer sets combined

Supplementary Figure S1: Example of gel electrophoresis results measuring PCR amplification rates of the original shark mini-barcode combined with (a) DNeasy Kit alone and (b) DNeasy Kit plus PowerClean. Lane assignments are the same in each gel and are as follows: Lane 1 = PS20, Lane 2 = PS21, Lane 3 = PS22, Lane 4 = PS23, Lane 5 = PS24, Lane $6=$ PS25, Lane $7=$ PS27, Lane 8 = PS28, Lane $9=$ PS29, Lane $10=$ PS30, Lane $11=$ PS32, Lane $12=$ reagent blank, Lane 13 = non-template control, Lane 14 = positive control. 
$100.0 \%$

$90.0 \%$

$80.0 \%$

$77.3 \%$

$70.0 \%$

$68.2 \%$

$68.2 \%$

$60.0 \%$

$56.8 \%$

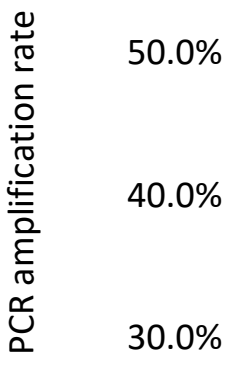

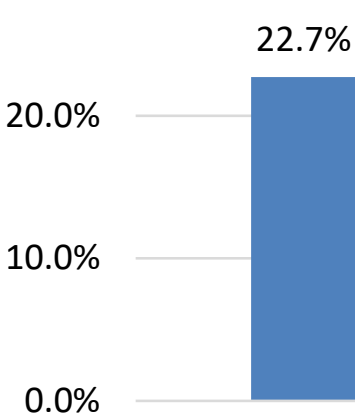

SH-D
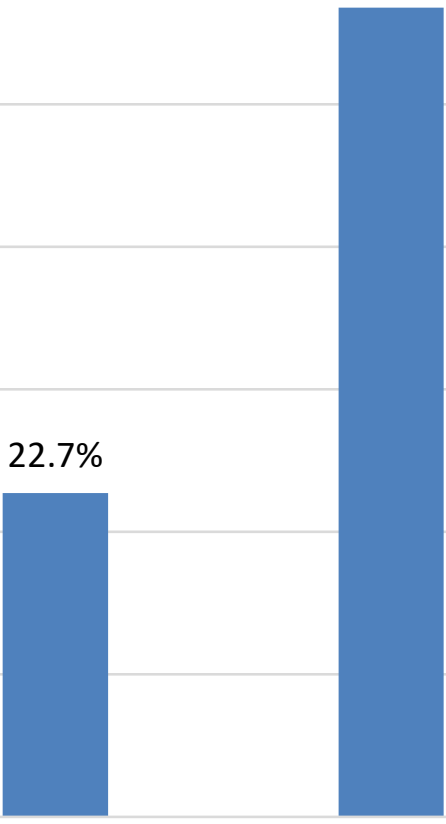

Shark mini

Shark mini V1

Shark mini V2

Combined

DNA mini-barcoding primer set 
(a)

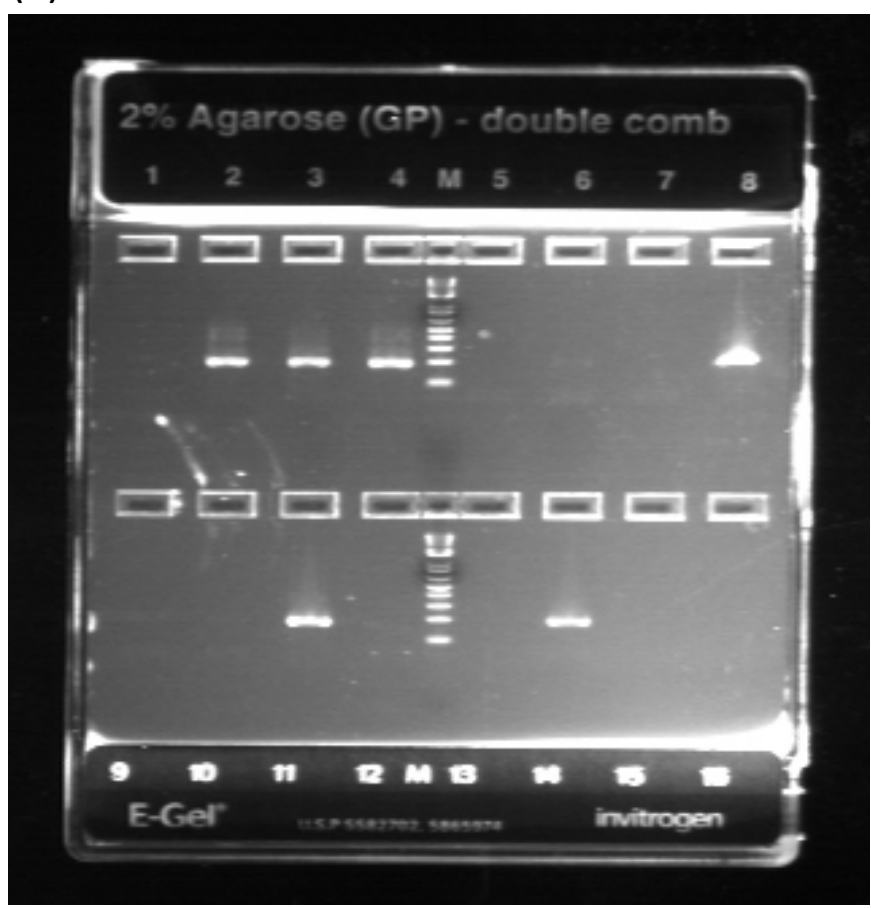

(b)

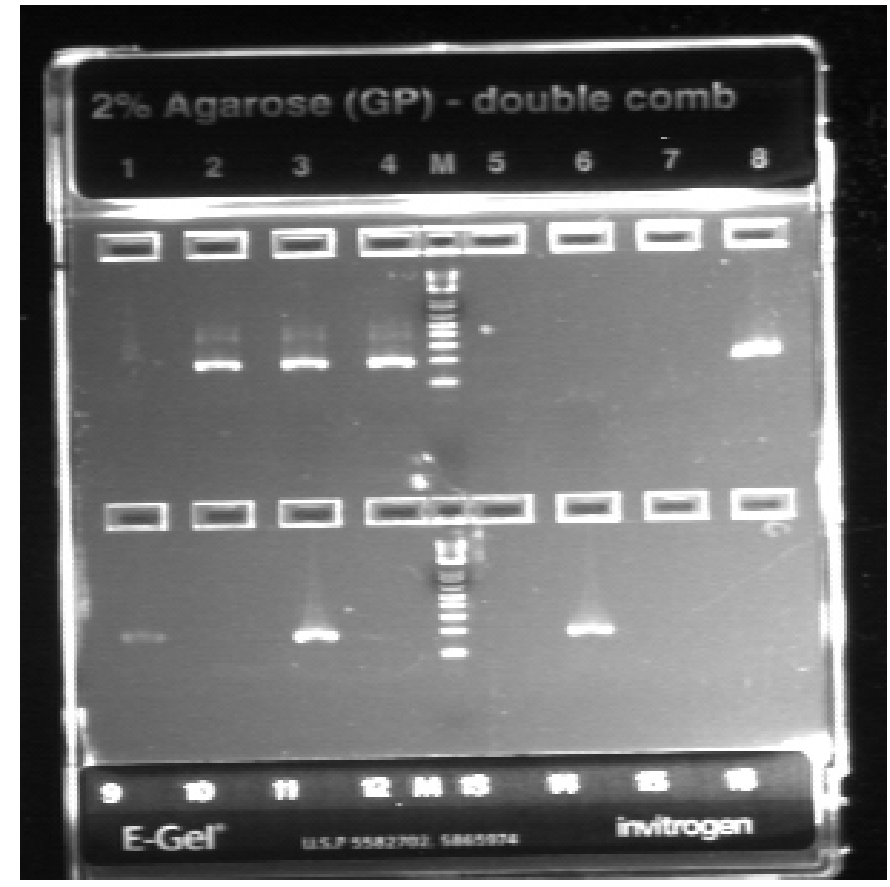

Supplementary Figure S1: Example of gel electrophoresis results measuring PCR amplification rates of the original shark mini-barcode combined with (a) DNeasy Kit alone and (b) DNeasy Kit plus PowerClean. Lane assignments are the same in each gel and are as follows: Lane 1= PS20, Lane 2 = PS21, Lane $3=$ PS22, Lane $4=$ PS23, Lane $5=$ PS24, Lane $6=$ PS25, Lane $7=$ PS27, Lane 8 = PS28, Lane $9=$ PS29, Lane 10 = PS30, Lane 11 = PS32, Lane 12 = reagent blank, Lane 13 = nontemplate control, Lane 14 = positive control. 
Table 1. Primer sequences for five primer sets compared in this study

\begin{tabular}{|c|c|c|c|c|c|}
\hline Primer set & Primer name & Direction & Primer sequence $\left(5^{\prime}-3^{\prime}\right)^{a}$ & $\begin{array}{l}\text { Barcode } \\
\text { length }\end{array}$ & Reference \\
\hline \multirow[t]{3}{*}{$\begin{array}{l}\text { Shark mini- } \\
\text { barcode }\end{array}$} & VF2_t1 & Forward & $\begin{array}{l}\text { TGTAAAACGACGGCCAGTCAACCAACCA } \\
\text { CAAAGACATTGGCAC }\end{array}$ & \multirow[t]{3}{*}{127 bp } & \multirow{2}{*}{$\begin{array}{l}\text { (Fields, et al., 2015; } \\
\text { Ivanova, Zemlak, } \\
\text { Hanner, \& Hebert, } \\
\text { 2007) }\end{array}$} \\
\hline & FishF2_t1 & Forward & $\begin{array}{l}\text { TGTAAAACGACGGCCAGTCGACTAATCAT } \\
\text { AAAGATATCGGCAC }\end{array}$ & & \\
\hline & $\begin{array}{l}\text { Shark COI- } \\
\text { MINIR }\end{array}$ & Reverse & AAGATTACAAAAGCGTGGGC & & (Fields, et al., 2015) \\
\hline \multirow[t]{3}{*}{$\begin{array}{l}\text { Shark mini- } \\
\text { barcode_V1 }\end{array}$} & VF2_t1 & Forward & See above & \multirow[t]{3}{*}{127 bp } & $\begin{array}{l}\text { (Fields, et al., 2015; } \\
\text { Ivanova, et al., 2007) }\end{array}$ \\
\hline & FishF2_t1 & Forward & See above & & \\
\hline & $\begin{array}{l}\text { Shark_Mini_V1 } \\
\text { _R }\end{array}$ & Reverse & AAGATTATTACAAAAGCRTGRGC & & Current study \\
\hline \multirow[t]{3}{*}{$\begin{array}{l}\text { Shark mini- } \\
\text { barcode_V2 }\end{array}$} & VF2_t1 & Forward & See above & \multirow[t]{3}{*}{127 bp } & $\begin{array}{l}\text { (Fields, et al., 2015; } \\
\text { Ivanova, et al., 2007) }\end{array}$ \\
\hline & FishF2_t1 & Forward & See above & & \\
\hline & $\begin{array}{l}\text { Shark_Mini_V2 } \\
\text { _R }\end{array}$ & Reverse & AAGATTATTACRAADGCRTGRGC & & Current study \\
\hline \multirow[t]{2}{*}{ Mini_SH-D } & Mini_SH-D_F & Forward & $\begin{array}{l}\text { CACGACGTTGTAAAACGACGGIACIGGITG } \\
\text { RACIGTITAYCCYCC }\end{array}$ & \multirow[t]{2}{*}{208 bp } & \multirow[t]{2}{*}{$\begin{array}{l}\text { (Shokralla, et al., } \\
\text { 2015) }\end{array}$} \\
\hline & Mini_SH-D_R & Reverse & $\begin{array}{l}\text { GGATAACAATTTCACACAGGGTRATICCIG } \\
\text { CIGCIAGIAC }\end{array}$ & & \\
\hline \multirow[t]{2}{*}{ Mini_SH-E } & Mini_SH-E_F & Forward & $\begin{array}{l}\text { CACGACGTTGTAAAACGACACYAAICAYA } \\
\text { AAGAYATIGGCAC }\end{array}$ & \multirow[t]{2}{*}{226 bp } & \multirow[t]{2}{*}{$\begin{array}{l}\text { (Shokralla, et al., } \\
\text { 2015) }\end{array}$} \\
\hline & Mini_SH-E_R & Reverse & $\begin{array}{l}\text { GGATAACAATTTCACACAGGCTTATRTTR } \\
\text { TTTATICGIGGRAAIGC }\end{array}$ & & \\
\hline
\end{tabular}


Table 2. Comparison of DNA extraction and PCR amplification results obtained for duplicate shark cartilage samples $(\mathrm{n}=44)$ tested with the original shark mini-barcode primer set. DNA concentrations and absorbance ratios are expressed as the average \pm standard deviation

\section{DNeasy Kit DNeasy Kit plus PowerClean}

Kit

\begin{tabular}{lcc}
\hline DNA concentration (ng/ul) & $69.6 \pm 70.3^{\mathrm{a}}$ & $23.4 \pm 13.1^{\mathrm{b}}$ \\
$\mathrm{A}_{260} / \mathrm{A}_{280}$ ratio $^{\mathrm{c}}$ & $1.7 \pm 0.5^{\mathrm{a}}$ & $1.6 \pm 0.4^{\mathrm{a}}$ \\
$\mathrm{A}_{260} / \mathrm{A}_{230}$ ratio $^{\mathrm{d}}$ & $0.6 \pm 0.3^{\mathrm{a}}$ & $3.3 \pm 3.0^{\mathrm{b}}$ \\
PCR amplification rate & $47.8 \%$ & $52.3 \%$ \\
PCR amplification consistency & $77.3 \%$ & $95.5 \%$
\end{tabular}

${ }^{\mathrm{ab}} \mathrm{A}$ different superscript letter in the same row indicates a significant difference between extraction methods, according to the Wilcoxon signed-rank test $(p<$ 0.05).

${ }^{\mathrm{c}}$ Ratios could not be determined for 7 DNeasy Kit replicates because the A280 value was not within the measuring range

${ }^{\mathrm{d}}$ Ratios could not be determined for 3 DNeasy Kit replicates and 14 DNeasy Kit + PowerClean Kit replicates because the A230 value was not within the measuring range 
Table 3. Sequencing rates and quality parameters obtained for shark cartilage samples tested in duplicate $(n=44)$ with three shark mini-barcode primer sets

\begin{tabular}{|c|c|c|c|c|c|}
\hline Primer Set & $\begin{array}{l}\text { Sequencing } \\
\text { method }\end{array}$ & $\begin{array}{l}\text { Sequencing } \\
\text { rate }\end{array}$ & $\begin{array}{l}\text { Sequence length } \\
\text { (bp) }\end{array}$ & HQ (\%) & Ambiguities (\%) \\
\hline \multirow[t]{2}{*}{ Shark mini-barcode } & Uni-directional & $56.8 \%$ & $107 \pm 11^{\mathrm{a}}$ & $41.4 \pm 15.4^{\mathrm{a}}$ & $0.00 \pm 0.00^{\mathrm{a}}$ \\
\hline & Bi-directional & $56.8 \%$ & $127 \pm 0^{b}$ & $70.6 \pm 17.1^{\mathrm{b}}$ & $0.16 \pm 0.39^{\mathrm{ab}}$ \\
\hline \multirow[t]{2}{*}{ Shark mini-barcode V1 } & Uni-directional & $54.5 \%$ & $105 \pm 17^{\mathrm{a}}$ & $29.3 \pm 24.6^{\mathrm{a}}$ & $0.00 \pm 0.00^{\mathrm{a}}$ \\
\hline & Bi-directional & $59.0 \%$ & $118 \pm 17^{b}$ & $47.9 \pm 35.4^{\mathrm{a}}$ & $0.31 \pm 0.57^{\mathrm{b}}$ \\
\hline \multirow[t]{2}{*}{ Shark mini-barcode V2 } & Uni-directional & $63.6 \%$ & $104 \pm 17^{\mathrm{a}}$ & $30.9 \pm 28.8^{\mathrm{a}}$ & $0.00 \pm 0.00^{\mathrm{a}}$ \\
\hline & Bi-directional & $65.9 \%$ & $119 \pm 14^{b}$ & $46.0 \pm 36.7^{a}$ & $0.08 \pm 0.32^{\mathrm{ab}}$ \\
\hline Combined $^{\mathrm{C}}$ & & $75 \%$ & $113 \pm 16$ & $44.2 \pm 30.6$ & $0.09 \pm 0.33$ \\
\hline
\end{tabular}

\footnotetext{
${ }^{\mathrm{ab}} \mathrm{A}$ different superscript letter in the same column indicates a significant difference, according to the Kruskal-Wallis $\mathrm{H}$ test and Dunn's post hoc test with the Bonferroni correction (adjusted $p<0.05$ ).

'Sequencing results for all primer sets combined
} 
Table 4. Species identified in the 18 shark cartilage products sequenced by at least one of the primer sets tested in this study. CITESlisted species are indicated with boldface. In cases where duplicate samples had different species identifications, the top matches are separated by a semicolon

\begin{tabular}{|c|c|c|c|c|c|}
\hline \multirow{2}{*}{$\begin{array}{l}\text { Sample } \\
\text { ID }\end{array}$} & \multirow{2}{*}{$\begin{array}{l}\text { Product } \\
\text { description }\end{array}$} & \multirow{2}{*}{$\begin{array}{l}\text { Sequencing } \\
\text { method }\end{array}$} & \multicolumn{3}{|c|}{ Primer Set } \\
\hline & & & Shark mini-barcode & Shark mini-barcode V1 & Shark mini-barcode V2 \\
\hline PS04 & $\begin{array}{l}\text { Shark cartilage } \\
\text { capsules }\end{array}$ & Bi-directional & Carcharhinus falciformis $^{\mathrm{ab}}$ & N/A & Carcharhinus falciformis ${ }^{\text {ab }}$ \\
\hline PS05 & $\begin{array}{l}\text { Shark cartilage } \\
\text { capsules }\end{array}$ & Bi-directional & N/A & Leucoraja ocellata & Leucoraja ocellata \\
\hline PS06 & $\begin{array}{l}\text { Shark cartilage } \\
\text { tablets }\end{array}$ & Bi-directional & Carcharhinus sorrah ${ }^{\mathrm{c}}$ & $\begin{array}{l}\text { Carcharhinus melanopterus }{ }^{\mathrm{cd}} \text {; } \\
\text { Carcharhinus spp. }^{\mathrm{d}}\end{array}$ & Carcharhinus melanopterus $^{\mathrm{a}}$ \\
\hline PS07 & $\begin{array}{l}\text { Shark cartilage } \\
\text { capsules }\end{array}$ & Bi-directional & $\begin{array}{l}\text { Carcharhinus falciformis } \\
\text { Carcharhinus melanopterus } \\
\text { Carcholi }\end{array}$ & N/A & Carcharhinus sorrah ${ }^{\text {abcd }}$ \\
\hline PS08 & $\begin{array}{l}\text { Shark cartilage } \\
\text { capsules }\end{array}$ & Bi-directional & Carcharhinus falciformis ${ }^{\mathrm{ab}}$ & N/A & Carcharhinus spp. $^{\text {ab }}$ \\
\hline PS13 & $\begin{array}{l}\text { Shark cartilage } \\
\text { capsules }\end{array}$ & Bi-directional & Carcharhinus sorrah & Carcharhinus sorrah $^{\mathrm{c}}$ & $\begin{array}{l}\text { Carcharhinus sorrah; } \\
\text { Carcharhinus spp. }\end{array}$ \\
\hline PS15 & $\begin{array}{l}\text { Shark cartilage } \\
\text { capsules }\end{array}$ & Bi-directional & Carcharhinus falciformis $^{\mathrm{a}}$ & Carcharhinus falciformis $^{\mathrm{a}}$ & $\begin{array}{l}\text { Carcharhinus melanopterus }{ }^{\mathrm{d}} \text {; } \\
\text { Carcharhinus falciformis }^{\mathrm{a}}\end{array}$ \\
\hline PS16 & $\begin{array}{l}\text { Shark cartilage } \\
\text { capsules }\end{array}$ & Bi-directional & N/A & Leucoraja ocellata & Leucoraja ocellata \\
\hline PS17 & $\begin{array}{l}\text { Shark cartilage } \\
\text { capsules }\end{array}$ & Bi-directional & Carcharhinus melanopterus $^{\mathrm{b}}$ & Negaprion acutidens ${ }^{\mathrm{abcd}}$ & N/A \\
\hline PS19 & $\begin{array}{l}\text { Shark cartilage } \\
\text { capsules }\end{array}$ & Bi-directional & $\begin{array}{l}\text { Carcharhinus falciformis } \\
\text { Carcharhinus melanopterus } \\
\text { Carche }\end{array}$ & $\begin{array}{l}\text { Carcharhinus falciformis } \\
\text { Carcharhinus melanopterus }\end{array}$ & $\begin{array}{l}\text { Carcharhinus falciformis } \\
\text { Carcharhinus melanopterus }\end{array}$ \\
\hline PS20 & $\begin{array}{l}\text { Shark cartilage } \\
\text { capsules }\end{array}$ & Bi-directional & N/A & Squalus acanthias & Squalus acanthias \\
\hline PS21 & $\begin{array}{l}\text { Shark cartilage } \\
\text { capsules }\end{array}$ & Bi-directional & Carcharhinus sorrah $^{\mathrm{a}}$ & Carcharhinus sorrah ${ }^{\mathrm{abc}}$ & $\begin{array}{l}\text { Carcharhinus sorrah }^{\text {cd; }} \\
\text { Carcharhinus spp. }\end{array}$ \\
\hline PS22 & $\begin{array}{l}\text { Shark cartilage } \\
\text { capsules }\end{array}$ & Bi-directional & Carcharhinus sorrah & $\begin{array}{l}\text { Carcharhinus } \\
\text { amblyrhynchoides }^{\text {bd }}\end{array}$ & $\begin{array}{l}\text { Carcharhinus melanopterus } \\
\text { Carcharhinus sorrah }\end{array}$ \\
\hline
\end{tabular}




\begin{tabular}{|c|c|c|c|c|c|}
\hline PS23 & $\begin{array}{l}\text { Shark cartilage } \\
\text { capsules }\end{array}$ & Bi-directional & Carcharhinus sorrah & $\begin{array}{l}\text { Carcharhinus leucas }{ }^{\mathrm{d}} \text {; } \\
\text { Carcharhinus sorrah }^{\text {acd }}\end{array}$ & Carcharhinus sorrah ${ }^{\mathrm{b}}$ \\
\hline PS28 & $\begin{array}{l}\text { Shark cartilage } \\
\text { capsules }\end{array}$ & Bi-directional & Prionace glauca & Prionace glauca & Prionace glauca \\
\hline PS29 & $\begin{array}{l}\text { Shark cartilage } \\
\text { capsules }\end{array}$ & Bi-directional & $\begin{array}{l}\text { Carcharhinus melanopterus }{ }^{\mathrm{c}} \text {; } \\
\text { Carcharhinus sorrahc; }^{\mathrm{c}}\end{array}$ & N/A & N/A \\
\hline PS30 & $\begin{array}{l}\text { Shark cartilage } \\
\text { capsules with } \\
\text { dogfish shark }\end{array}$ & Bi-directional & N/A & N/A & Carcharhinus spp. $^{\text {b }}$ \\
\hline PS32 & $\begin{array}{l}\text { Shark cartilage } \\
\text { capsules }\end{array}$ & Bi-directional & Galeorhinus galeus & Galeorhinus galeus & Galeorhinus galeus \\
\hline
\end{tabular}

Identification included the use of character analysis

bidentification was only successful for one of the duplicate samples

'Sequence had secondary species matches with $\geq 99.22 \%$ genetic similarity to the top species match that could not be ruled out with character analysis

dop species match had $<98 \%$ genetic similarity to query sequence 